\title{
ECOLOGY AND LIFE HISTORY OF THE \\ RHYTIDOPONERA IMPRESSA GROUP \\ (HYMENOPTERA:FORMICIDAE) \\ I. HABITATS, NEST SITES, AND FORAGING BEHAVIOR
}

\author{
By Philip S. Ward ${ }^{1}$ \\ Department of Zoology, University of Sydney, \\ N.S.W. 2006, Australia
}

\section{INTRODUCTION}

The ponerine ants of the genus Rhytidoponera constitute a rich assemblage of species, widespread throughout Australia, with lesser representation in Melanesia and adjacent regions (Brown, 1958; Wilson, 1958). On the Australian mainland they have collectively occupied a broad range of habitats, and often rank among the more abundant members of an ant community. Considerable interest centers on the unusual habit, apparently widespread in the genus, of reproduction by mated "workers" in lieu of a morphologically differentiated dealate queen (Brown, 1953, 1954; Whelden, 1957, 1960; Haskins \& Whelden, 1965).

The Rhytidoponera impressa group consists of a small, distinctive cluster of species occurring in mesic habitats (mostly rainforest and wet sclerophyll) along the east coast of Australia and in New Guinea. Until recently, the impressa group was thought to comprise no more than three species, all reproducing by means of distinct winged queens (Brown, 1953, 1954; Haskins \& Whelden, 1965). However, recent studies of systematic relationships and colony structure in the impressa group have revealed the presence of at least 5 closely related species and the occurrence of reproduction by both queens and mated workers (Ward, 1978, 1980).

There is a notable paucity of detailed ecological studies on rainforest ponerines in general, and there have been no extensive field studies on Rhytidoponera. This paper summarizes information on habitat and nest site preferences, colony densities, and various aspects of foraging, in the impressa group. A second paper describes life cycle and reproductive patterns (Ward, 1981).

\footnotetext{
${ }^{1}$ Present address: Department of Entomology, University of California, Davis, California 95616

Manuscript received by the editor April 15, 1981.
} 


\section{METHODS}

Data were gathered during a survey of the Rhytidoponera impressa group from approximately 100 mesic forest sites in eastern Australia and New Guinea. A detailed tabulation of these collection sites is given in Ward (1978). Field work was carried out from October, 1974 to October, 1978, with a few additional collections in May-July, 1980. Voucher specimens from these collections have been deposited in the Australian National Insect Collection (ANIC), CSIRO, Canberra.

In rainforest and wet sclerophyll forest the collection procedure was as follows: colonies of the impressa group were sought by examining all rotting logs, loose stones and other potential nest sites which were encountered during a more or less random (i.e. undirected) walk through a tract of suitable forest. In most localities a tally was kept of the number of "potential nest sites" (logs and stones) sampled. The "rotting log" count was confined to moist rotten logs in middle to late stages of decay, with numerous preformed cavities (corresponding roughly to the "zorapteran" and "passalid" stages of Wilson, 1959), since field observations showed that recently fallen or dessicated logs were rarely inhabited. If a single large log was dissected in two places more than 1 meter apart it was counted as two potential nest sites. Records from rotting logs include a few instances where ants also nested in soil below the log. Stones ranging in areal size from about 100 to $1500 \mathrm{~cm}^{2}$ were recorded as potential nest sites if they rested completely on the ground and could be easily overturned. Fallen epiphytic fern masses on the rainforest floor were also considered potential nest sites and were examined and counted in areas where they occurred. Almost invariably, a single colony occupied only one nest site, so the terms "colony" and "nest" are used in equivalently in this paper.

When an impressa group colony was located, an attempt was usually made to collect the entire colony contents, i.e. all workers, reproductives, and brood. This entailed considerable excavation of rotting wood and/or soil. Where only colony fragments were believed to be collected, this was noted.

Collected colonies were returned to the lab and their contents enumerated. A few were maintained in modified Janet or Lubbock nests. The majority were frozen for electrophoresis.

Field observations of foraging behavior, colony movement, alate 
dispersal, and mating behavior were also made. In addition, field observations and collections of related Rhytidoponera species from Australia, New Guinea, and New Caledonia provided some comparative data.

\section{RESULTS}

\section{Habitat Preferences}

The known members of the Rhytidoponera impressa group and their respective distributions are as follows (Ward, 1980): chalybaea Emery (= cyrus Forel), New South Wales, southern Queensland, New Zealand (introduced); confusa Ward, Victoria, New South Wales, southern Queensland; enigmatica Ward, New South Wales; impressa Mayr, Queensland; and purpurea Emery (= splendida Forel), northern Queensland, New Guinea.

Most species in the impressa group occupy a considerable range of latitude, altitude and forest types; and all species show partial sympatry with at least one other species (Table 1). In this context, a sympatric association is defined as the occurrence of two (or more) species within the dispersal range of their alates. In all cases of sympatry, non-conspecific nests were located within several hundred meters of one another, and in most instances within 50 meters. Despite the overlap between species, differences in habitat preferences are apparent.

$R$. confusa is essentially a species of wet sclerophyll forest and temperate rainforest. In Victoria and southern New South Wales it is principally confined to lowland wet sclerophyll, and does not occupy cool temperate rainforest of the type dominated by such trees as Nothofagus, Quintinia, and/or Atherosperma. At the northern limit of its range, confusa is restricted to temperate and subtropical rainforest at moderate to high elevations. Thus, there is an inverse relationship between elevation and latitude (Figure 1), and the regression of altitude on latitude indicates an average shift of about $70 \mathrm{~m}$ per degree latitude.

In contrast to confusa, chalybaea is common in subtropical rainforest of northern New South Wales and southern Queensland (where confusa is rare or absent). At the southern limit of its distribution, chalybaea is confined to disturbed lowland habitats. Thus, in the Sydney region, it occurs commonly in well-watered parks and gardens, and only penetrates wet sclerophyll and 


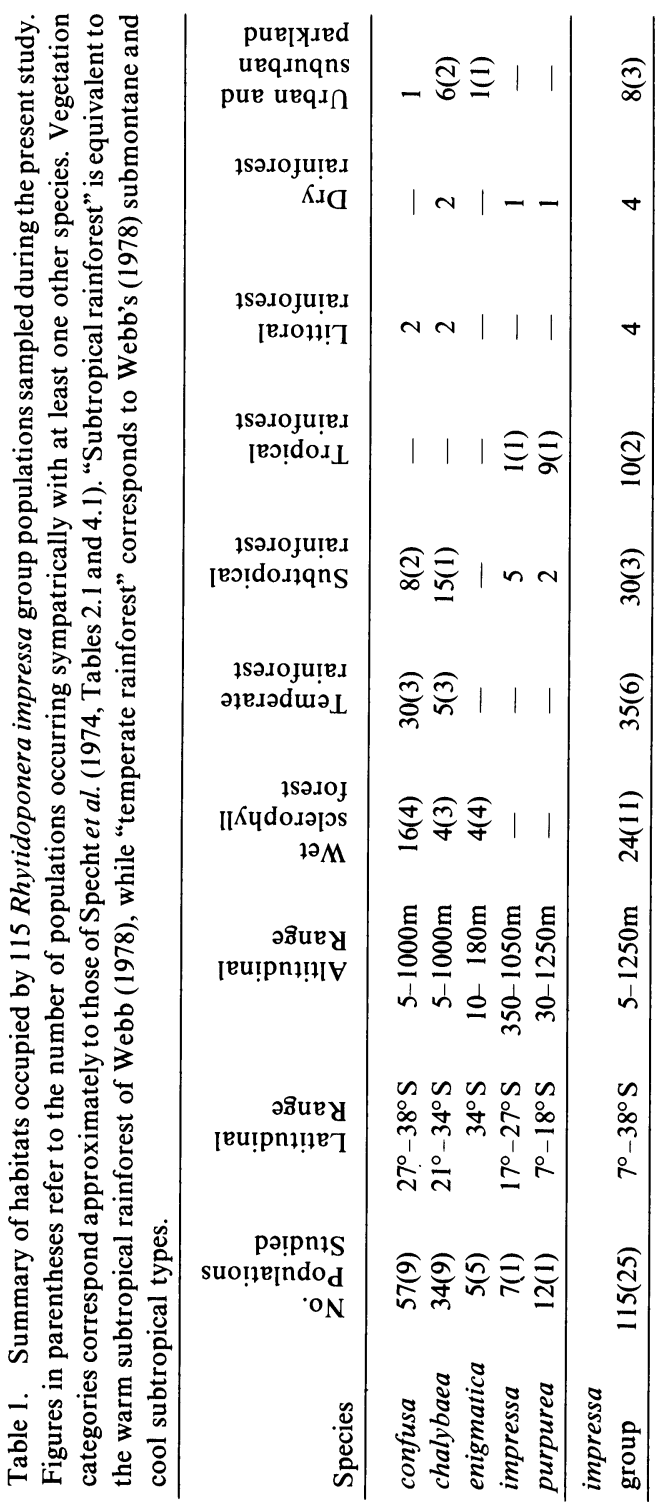




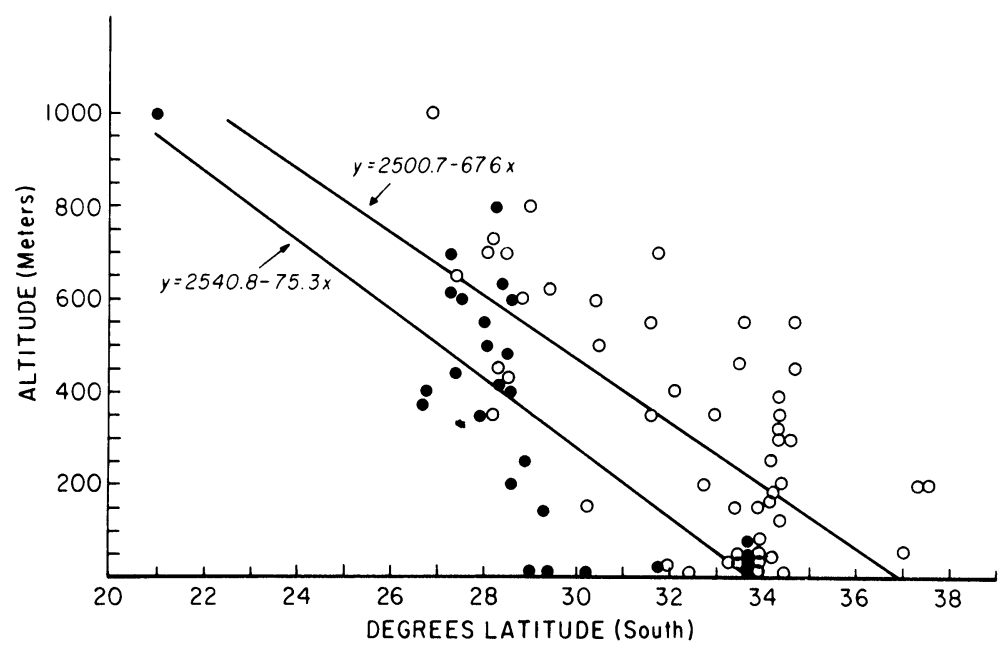

Figure 1. Altitude and latitude of 57 populations of confusa (open circles) and 34 populations of chalybaea (closed circles). Regressions of altitude on latitude for confusa (upper line) and chalybaea (lower line) are highly significant $(\mathrm{p}<.001)$.

rainforest gullies which are ecologically very disturbed, i.e. heavily encroached with introduced weeds such as Lantana, Ligustrum and Tradescantia.

Sympatric associations between chalybaea and its sibling species, confusa, occur in some of these disturbed gully sites, with confusa preferentially occupying the vegetationally less disturbed portions of the gully. These two species also occur sympatrically in stands of undisturbed temperate and subtropical rainforest in northern New South Wales and southern Queensland. In this region chalybaea tends to occupy more xeric microhabitats than confusa, but in one locality (an isolated patch of rainforest at Boonoo Boonoo Falls, N.S.W.) no obvious nest site or microhabitat differences were found between the two species, which nested within a few meters of one another.

$R$. chalybaea also shows an altitudinal shift with increasing latitude (Figure 1) and tends to occur at lower elevations than confusa. The general picture is one of partial ecological differentiation between these two species despite their very close morphological resemblance (cf. Ward, 1980). 
Table 2. Nest site records for the Rhytidoponera impressa group, excluding small, incipient colonies ( $\leq 20$ workers). Figures in parentheses represent the percentages (for each species) of colonies occupying a given type of nest site.

\begin{tabular}{lcccc}
\hline Species & $\begin{array}{c}\text { Rotten } \\
\text { Logs }\end{array}$ & Stones & $\begin{array}{c}\text { Fallen } \\
\text { Epiphytes }\end{array}$ & Total \\
\hline confusa & 258 & 143 & 11 & 412 \\
chalybaea & $(62.6)$ & $(34.7)$ & $(2.7)$ & \\
& 145 & 19 & 1 & 165 \\
impressa & $(87.9)$ & $(11.5)$ & $(0.6)$ & \\
& 13 & 1 & 0 & 14 \\
purpurea & $(92.9)$ & $(7.1)$ & $(0.0)$ & \\
& 34 & 0 & 0 & 34 \\
enigmatica & $(100.0)$ & $(0.0)$ & $(0.0)$ & \\
& 0 & 21 & 0 & 21 \\
all species & $(0.0)$ & $(100.0)$ & $(0.0)$ & \\
& 450 & 184 & 12 & 646 \\
\hline
\end{tabular}

$R$. enigmatica is a localized species, known only from wet sclerophyll vegetation in sandstone gullies (6 sites, including two ANIC records) and urban parkland (1 site), the latter record coming from an area where the original habitat would have been sandstone gully vegetation. The range of elevation from which it has been recorded is 10 to 180 meters. Thus, with regard to habitat preference enigmatica is the most stenotopic species. Most of the known populations are in sympatry with, or in close proximity to, populations of confusa and/or chalybaea.

The 7 impressa populations studied come from tropical rainforest (1), subtropical rainforest (5), and dry rainforest (1). These data, along with 30 other collection records in the ANIC, indicate that impressa is confined to Queensland rainforest at altitudes ranging from $30 \mathrm{~m}$ to $1050 \mathrm{~m}$.

Based on the 12 populations studied here plus additional records from the ANIC and from Wilson (1958), purpurea is recorded from subtropical and tropical rainforest (and one population from dry microphyll rainforest on the Mt. Windsor Tableland) in northern Queensland $(30 \mathrm{~m}$ to $1200 \mathrm{~m})$, and from tropical montane rainforest $(600 \mathrm{~m}$ to $1300 \mathrm{~m})$ in Papua New Guinea. In north Queensland it occurs in both primary-growth and partially disturbed rainforest, 
while New Guinea records indicate a predilection for second-growth montane rainforest.

\section{Nest Site Preferences and Densities}

Members of the impressa group are found nesting mostly in rotten logs and under stones. Nests are multi-chambered, but not highly fragmented, seldom penetrating deeper than $15-20 \mathrm{~cm}$ into soil, or occupying more than $1 \mathrm{~m}$ length of rotting log. Nest entrances are cryptic, without conspicuous mounds of excavated material.

Fallen epiphytes on the rainforest floor are occasionally utilized as nest sites by confusa and chalybaea. Duringthe present study no colonies were found in living epiphytes on trees, although there are single records of a colony-founding purpurea queen (Brown, 1954) and a mature purpurea colony (Wilson, 1958) from fern epiphytes on rainforest trees.

Nest site records from the present study are summarized in Table 2 which lists, for each species, the number of colonies collected from rotten logs, under stones, and in fallen epiphytes. Excluded from this table are a small number of single records from other nest sites. Thus confusa was also found nesting in a Banksia lignotuber, in a rotting bracket fungus, directly in the soil, and (twice) in an abandoned termite mound in rainforest. A chalybaea colony was located under the bark sheath of an Archontophoenix palm, and in urban areas this species occupied less orthodox nest sites (e.g. in and under rusting metal, under concrete slabs, and in crevices along a stone wall). Three purpurea colonies (two in north Queensland, one in Papua New Guinea) were observed nesting in cavities in the trunks of living rainforest trees, and in New Guinea this species may be primarily an arboreal nester (Wilson, 1958; records in ANIC).

Table 2 shows that there is a clear trend towards greater specialization in the rotten log nest site in species of more tropical latitudes. The difference between confusa and chalybaea with respect to numbers of logs and stones utilized is highly significant $\left(\mathrm{x}_{1}^{2}=33.0, \mathrm{p}<.001\right)$ and the difference between chalybaea and purpurea is also significant $\left(\mathrm{x}_{1}^{2}=4.4, \mathrm{p}<.05\right)$. In contrast to all others, enigmatica (the localized species of wet sclerophyll gullies) appears to nest exclusively under stones.

In 70 populations (from 63 localities, due to some sympatry) a tally was kept of the number of "potential" nest sites (rotten logs, 


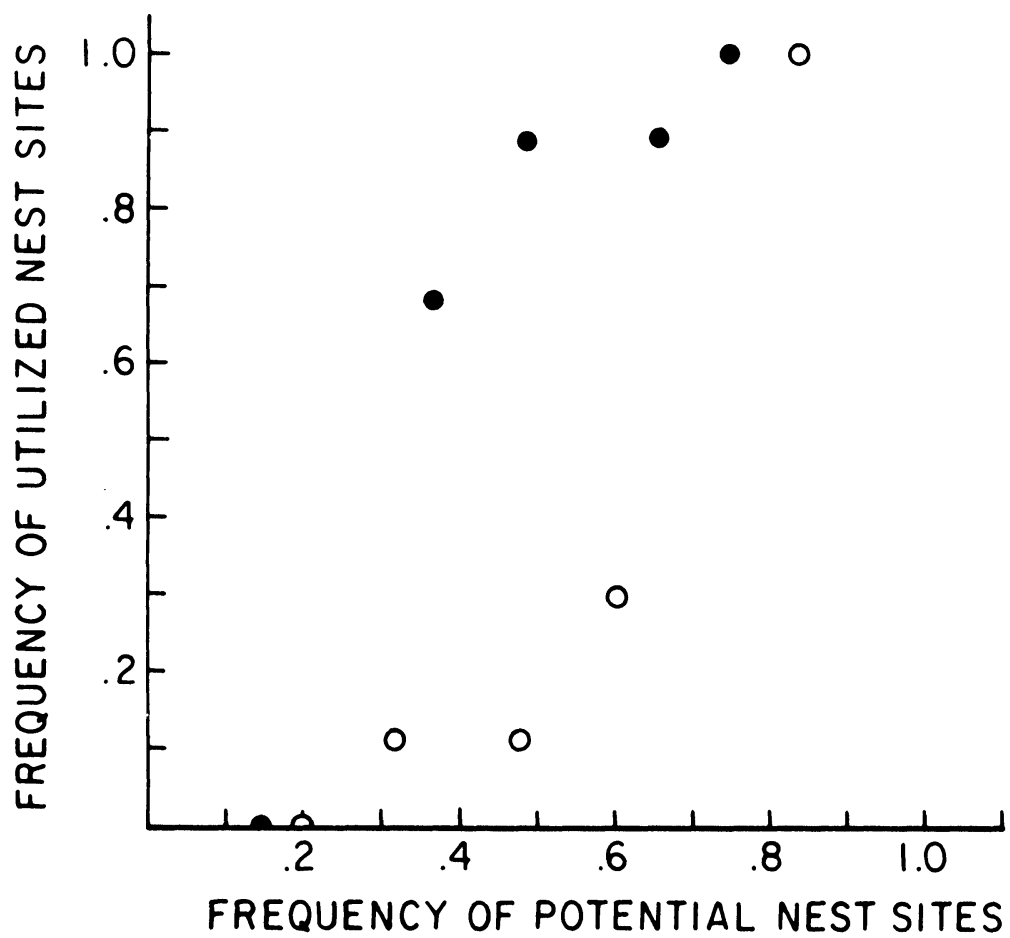

Figure 2. Within-species frequencies of utilized nest sites as a function of potential nest site frequencies, for 5 impressa group species. Closed circles refer to log nest sites, open circles to stones.

stones, fallen epiphytes) encountered as well as the number of actual nest site occupancies (Table 3). It seems clear that nest site availability varies from species to species. For both rotten $\log$ and stone nest sites there are positive correlations $(r=0.94, p<.02$, in both instances, arcsine transformed data) between the proportion of a species' colonies found in a particular nest site and the relative frequency of that nest site for the species (Figure 2). This suggests that species-specific preferences are partly a function of nest site availability. (No such correlation is found for fallen epiphytesconfusa showns the highest preference for this nest site despite its relative rarity in the southern rainforests; however, the numbers are in all instances rather low.)

The relative abundances of species can be crudely compared by 
Table 3. Numbers of potential nest sites (pns) sampled and actual nests encountered, for 70 impressa group populations.

\begin{tabular}{|c|c|c|c|c|c|c|}
\hline \multirow{4}{*}{$\frac{\text { Species }}{\text { confusa }}$} & \multicolumn{2}{|c|}{$\begin{array}{l}\text { No. } \\
\text { populations }\end{array}$} & \multirow{2}{*}{$\frac{\text { Logs }}{1838}$} & \multirow{2}{*}{$\begin{array}{c}\text { Stones } \\
2984\end{array}$} & \multirow{2}{*}{$\frac{\text { Epiphytes }}{92}$} & \multirow{2}{*}{$\frac{\text { Tota }}{4914}$} \\
\hline & 37 & no. pns & & & & \\
\hline & & no. nests & 227 & 98 & 8 & 333 \\
\hline & & nests/pns & .124 & .033 & .087 & .068 \\
\hline \multirow[t]{3}{*}{ chalybaea } & 22 & no. pns & 1164 & 1136 & 70 & 2370 \\
\hline & & no. nests & 141 & 17 & 1 & 159 \\
\hline & & nests/pns & .121 & .015 & .014 & .067 \\
\hline \multirow[t]{3}{*}{ impressa } & 4 & no. pns & 260 & 126 & 7 & 393 \\
\hline & & no. nests & 8 & 1 & 0 & 9 \\
\hline & & nests/pns & .031 & .008 & .000 & .023 \\
\hline \multirow[t]{3}{*}{ purpurea } & 5 & no. pns & 404 & 109 & 24 & 537 \\
\hline & & no. nests & 21 & 0 & 0 & 21 \\
\hline & & nests/pns & .052 & .000 & .000 & .039 \\
\hline \multirow[t]{3}{*}{ enigmatica } & 2 & no. pns & 105 & 561 & - & 666 \\
\hline & & no. nests & 0 & 15 & & 15 \\
\hline & & nests/pns & .000 & .027 & & .027 \\
\hline \multirow[t]{3}{*}{ all species } & 70 & no. pns & 3771 & 4916 & 193 & 8880 \\
\hline & & no. nests & 397 & 131 & 9 & 537 \\
\hline & & nests/pns & .105 & .270 & .047 & .060 \\
\hline
\end{tabular}

examining the proportion of potential nest sites which are occupied. (The desirable complementary data on absolute densities of potential nest sites for different geographical regions and habitats are not available). Comparing the density figures (Table 3) for confusa and chalybaea, the former occupies a significantly greater proportion of stone nest sites than chalybaea $\left(\mathrm{x}_{1}^{2}=9.7, \mathrm{p}<.01\right)$, but no differences exist in the proportion of suitable rotten logs occupied, and the overall nest densities (considering all potential nest sites) are the same for the two species. Nest densities are considerably lower for impressa, purpurea, and enigmatica. Rhytidoponera confusa and chalybaea utilize a significantly greater proportion of rotten logs than impressa and purpurea (contingency $\mathrm{x}^{2}, \mathrm{p}<.001$, for all four comparisons), despite the greater importance of rotting logs as nest sites in the more northerly (tropical) species. This may be partly the result of greater competition for nest sites in the species-rich tropical rainforests. $R$. confusa and chalybaea are often common and dominant ants in temperate and subtropical rainforests, respectively, of New South Wales and southern Queensland where the 
numbers of sympatric rainforest ant species are probably about onequarter to one-half that experienced by purpurea in north Queensland rainforest.

It is unclear why there is a disproportionate decline in the utilization of stones as nest sites in the more tropical members of the impressa group (Table 3) and perhaps for tropical rainforest ants in general (cf. Wilson, 1959, p. 440). One possibility is that in subtropical and tropical rainforests on well-drained soils, stones frequently lie on subsoil below the thin organic horizon and offer an environment poorer in immediate food resources and more demanding for nest excavation than rotting logs. In temperate and some subtropical rainforests of New South Wales, soil horizons tend to be less sharply stratified and/or litter decomposition is slower, so that humic material extends below the level of loose stones.

\section{Effects of Sympatry}

Nest site densities for sympatric and allopatric populations of confusa and chalybaea are given in Table 4 . Both species occupy a significantly greater proportion of $\log$ nest sites in allopatric populations (contingency $\mathrm{x}^{2}, \mathrm{p}<.01$ and $\mathrm{p}<.001$, for confusa and chalybaea respectively) and confusa inhabits a greater proportion of stone nests sites allopatrically $\left(\mathrm{x}_{1}^{2}=5.4, \mathrm{p}<.05\right)$. The lower sympatric densities of confusa and chalybaea could be a result of sympatric associations occurring in more marginal environments. However, the combined sympatric nest densities are very similar to the allopatric densities of both species. There are no significant differences between the total proportion of rotting logs occupied sympatrically and the proportion utilized allopatrically by either confusa $\left(\mathrm{x}_{1}^{2}=0.7\right)$ or chalybaea $\left(\mathrm{x}_{1}^{2}=1.8\right)$. The combined sympatric nest density under stones is the same as that for allopatric confusa populations. While these results could be coincindental, it seems more reasonable to conclude that sympatry has a depressant effect on relative abundance, and that competition for nest sites, food, or foraging space is important.

\section{Other Sympatric Congeners}

Other, more distantly related Rhytidoponera species also cooccur with members of the impressa group. $R$. victoriae (s.l.) is a common species (or complex of species) present in rainforest and other mesic habitats along the entire east coast of Australia. $R$. 


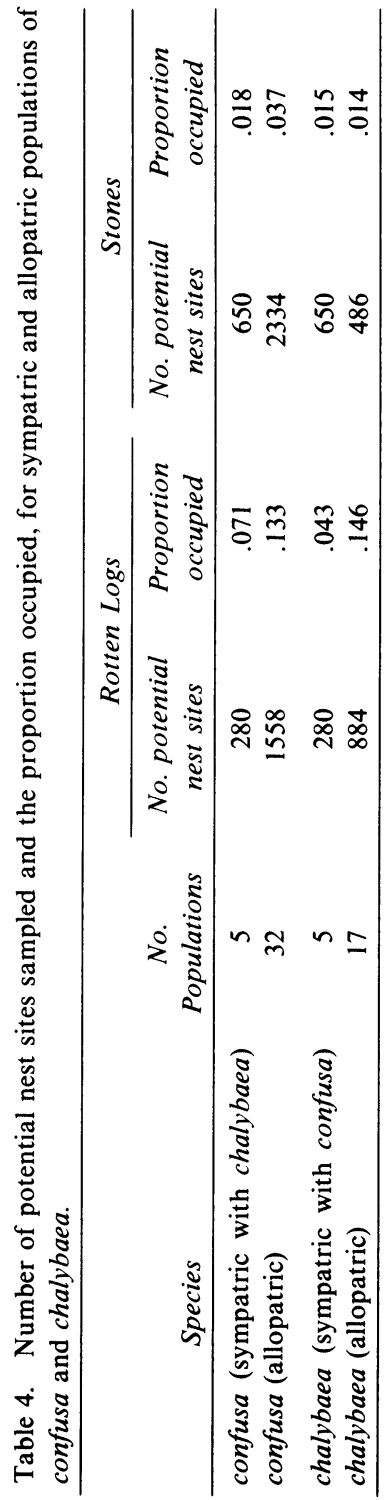


victoriae is considerably smaller than the impressa group species, and nests preferentially under stones.

In some north Queensland localities, purpurea or impressa coexist with one of several small Rhytidoponera species (e.g. chnoopyx and kurandensis nesting in logs and under stones) and with one of several larger species (scaberimma and related species, nesting in logs and directly in the soil). There are no rainforest Rhytidoponera of comparable size to the impressa group species that regularly coexist with the latter with the exception of croesus (s.l.), which nests in rotten logs and in tree trunks in rainforest and wet sclerophyll of New South Wales and southern Queensland. $R$. croesus appears to be generally uncommon, and in fact averages slightly smaller than chalybaea, confusa and impressa to a degree which may significantly reduce prey size overlap (see below).

Colonies of other Rhytidoponera species are virtually never found occupying the same nest site as an impressa group colony even though other medium to large ponerines such as Amblyopone australis, Leptogenys hackeri and Prionogenys podenzanai are occasionally found nesting in close proximity to an impressa group colony (e.g. under the same stone, or in adjacent cavities in a log).

\section{Colony Movement}

It appears that species in the impressa group are prone to move colonies from one nest site to another rather frequently. For example, in one rainforest population of confusa (Royal National Park, N.S.W.) eight stones under which colonies had been briefly located and otherwise left undisturbed were examined one week later: half were unoccupied. Three weeks later, only two colonies remained under the stones. While the censussing no doubt constituted a disturbance conducive to nest-movement, it demonstrates nevertheless the readiness with which colony movement is carried out.

During the course of field collections, vacated nest chambers were occasionally encountered (under stones or in rotten logs) whose previous occupants could be traced to an impressa group species on the basis of cocoon remains in the middens. Moreover, colony movement involving transport of brood and other workers was observed several times in chalybaea (and in other Rhytidoponera species outside the impressa group) (Ward, 1981). 
Foraging and Food-Retrieval

Members of the Rhytidoponera impressa group are partly predacious on other arthropods, but also scavenge for dead insects, seeds, animal feces, etc. Capture of live prey is achieved by a short lunge forward, coincindent with rapid closure of the outstretched mandibles. Prey thus captured are subdued by stinging.

In most species, foraging occurs principally on the ground, among leaf litter and rotting logs. However, purpurea workers were frequently observed foraging on low foliage of understorey plants, as well as on the rainforest floor, in north Queensland. In Papua New Guinea this species nests (at least partly) arboreally, but limited observations (Wau; September, 1975) suggests that it tends to forage downward from the nest entrance. Urban and suburban populations of chalybaea, noted for their unusual nest sites (above), usually forage on the ground and on low vegetation, in damp treeshaded situations. On one occasion chalybaea workers were observed foraging in a house in an urban residential area of Sydney.

Foraging is not restricted to any particular time of the day or season, although activity decreases noticeably towards the middle of the day (and in the winter). Periods of clear warm weather after rain seem particularly conducive to high levels of foraging activity.

Field observations indicate that workers are usually lone foragers, although occasionally several individuals co-operatively transport a large food item back to the nest. Sometimes this occurs close to the nest entrance, seemingly as a result of fortuitous encounters of a heavily-laden forager with other workers. In lab colonies of chalybaea, single workers struggling with a large prey item in a food arena were observed to make movements of the gaster suggesting stridulation. On the other hand, chemical recruitment to food sources does occur, although this behavior is rudimentary in comparison to the mass-recruitment patterns of some higher ants. It is readily demonstrated by placing large food baits (e.g. chunks of tuna fish or large insects) close to a nest. Workers which discover the food and return to the nest with a portion of the bait can be observed dragging the tips of their gasters along the ground, and subsequent outward-bound foragers follow the same path to the food (field observations on chalybaea and purpurea). Large pieces of the bait are retrieved co-operatively by several workers; smaller portions are carried by single foragers. 
When such baiting experiments are carried out, there appears to be little active defense of the food by Rhytidoponera workers. When baits are partially occupied by other smaller but mass-recruiting ant species, such as Pheidole, Rhytidoponera workers adopt a "graband-run" strategy. This is illustrated by the following observations on purpurea in rainforest near Cape Tribulation, north Queensland (5 June 1980).

A purpurea colony was located in the trunk of a living palm tree, in a cavity $60 \mathrm{~cm}$ above ground. Workers were foraging down the palm trunk and on the adjacent rainforest floor. A small chunk of tuna fish was placed on a stone, $1.5 \mathrm{~m}$ from the palm tree, and close to a purpurea forager which soon located the bait. It grasped a small piece of the tuna and returned to the nest, dragging the end of its gaster along the ground. A few minutes later, a worker (possibly the same individual) emerged from the nest entrance and returned to the bait by exactly the same trail. By this time, the remaining tuna bait was in two pieces, each attended by 2-3 workers of a Meranoplus $\mathrm{sp}$. The purpurea worker carefully circled around one piece of tuna to an unoccupied corner and grabbed it, inadvertently getting a Meranoplus worker at the same time. The two briefly grappled, and the purpurea worker dropped the food and retreated several centimeters. It then approached the second piece of tuna, edged in towards another exposed corner, swiftly grabbed it (this time without a Meranoplus worker), and hurriedly departed for the nest by a different route.

Unrecruited workers of the impressa group apparently forage randomly, without laying a continuous odour trail, but upon locating food they return directly to the nest. It is unclear what method(s) of orientation are utilized. Any explanation must take into account the observation that foraging occurs nocturnally as well as diurnally (at least in confusa and chalybaea).

\section{Food Diversity and Size}

The great majority of food items collected by impressa group workers are small, individual objects brought in by single foragers. Eighty-one food items were returned to a single chalybaea nest observed over a total of 8 hours (Table 5). Of these, one item (an earthworm) was transported by four workers; the remaining food items (encompassing 56 arthropods, 17 Ficus seeds or pieces of fruit, and 7 pieces of miscellaneous organic material) were carried by 


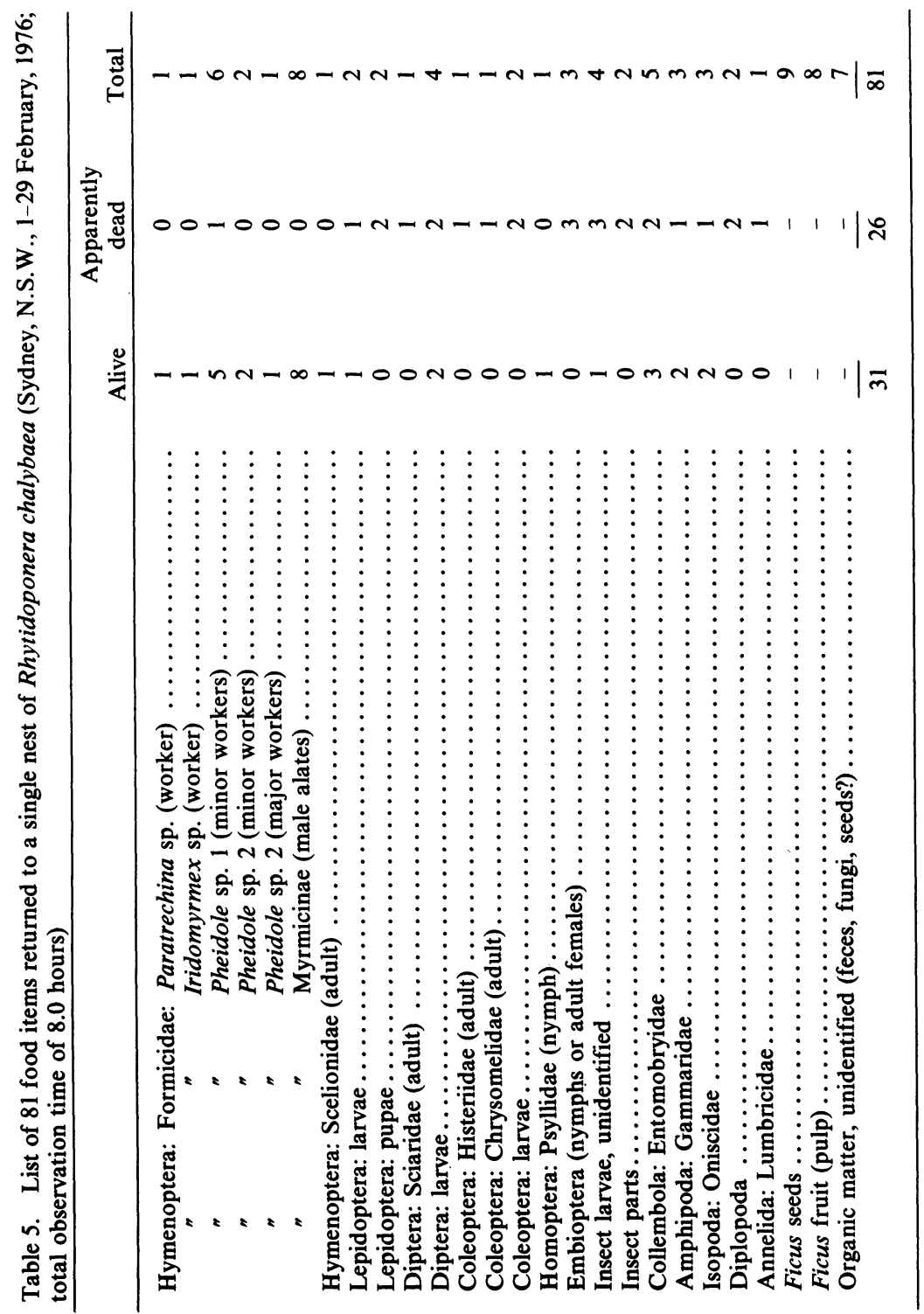


Table 6. List of 19 food items returned to a single nest of Rhytidoponera croesus s.l. (Royal National Park, N.S.W., 26 January, 1976) over a three-hour observation period.

\begin{tabular}{|c|c|c|}
\hline Hymenoptera: Formicidae: & Paratrechina sp. (worker) .............. & 1 \\
\hline$" 1$ & Solenopsis sp. (worker) ............... & 1 \\
\hline$"$ & Chelaner sp. (worker) $\ldots \ldots \ldots \ldots \ldots \ldots$ & 1 \\
\hline$" \quad$ " & Myrmicinae (male alate) $\ldots \ldots \ldots \ldots \ldots \ldots$ & 1 \\
\hline Hymenoptera: Pteromalidae & (adult) $\ldots \ldots \ldots \ldots \ldots \ldots \ldots \ldots \ldots \ldots$ & 1 \\
\hline Lepidoptera: adult microlepi & idopteran $\ldots \ldots \ldots \ldots \ldots \ldots \ldots \ldots \ldots \ldots \ldots$ & 1 \\
\hline Lepidoptera: larvae....... & $\ldots \ldots \ldots \ldots \ldots \ldots$ & 1 \\
\hline Diptera: Nematocera (adults & & 2 \\
\hline Diptera: Brachycera (adults) & & 2 \\
\hline Coleoptera: Chrysomelidae ( & (adult) $\ldots \ldots \ldots \ldots$ & 1 \\
\hline Homoptera: Coccoidea (nym & nph) $\ldots \ldots \ldots \ldots$ & 1 \\
\hline Homoptera: Cicadellidae (ny & ymph $\ldots \ldots \ldots \ldots \ldots$ & 1 \\
\hline Insect larva, unidentified ... & $\ldots \ldots \ldots \ldots \ldots$ & 1 \\
\hline Unidentified insect legs .. & 8) & 2 \\
\hline Acarina (small mite)....... & $\ldots \ldots \ldots \ldots \ldots \ldots \ldots \ldots \ldots \ldots \ldots \ldots \ldots$ & 1 \\
\hline Mammalian (?) excrement, v & with veg. matter and insect parts .......... & 1 \\
\hline & & 19 \\
\hline
\end{tabular}

single workers. Thirty-one (55\%) of the 56 arthropod items were alive when retrieved from their captors (near the nest entrance). Some of the remaining items may have been killed or paralyzed during capture; others were clearly scavenged as dead material.

It is of some interest to note that $19(34 \%)$ of the 56 arthropod items consisted of other ant species (including alates). Some of these ants, particularly alates, may have been injured or dying when collected. On the other hand, predation on healthy, active worker ants was observed first-hand in the field: chalybaea workers from the Sydney University population were seen preying at the soil entrances of Pheidole nests, grabbing workers as they emerged.

For comparison with another similar-sized, rainforest species of Rhytidoponera outside the impressa group, Table 6 lists the food items returned to a Rhytidoponera croesus nest over a three-hour observation period. The mean head widths for workers of croesus and chalybaea are $1.25 \pm 0.03$ s.d. $(\mathrm{n}=8)$ and $1.36 \mathrm{~mm} \pm 0.08$ s.d. $(\mathrm{n}=80)$, respectively. Although there is considerable similarity in food items taken by the two species as measured by ordinal taxonomic categories, an analysis of food size (Figure 3 ) reveals that the mean food item length of croesus $(2.5 \mathrm{~mm})$ is significantly less than that of chalybaea $(3.5 \mathrm{~mm})(\mathrm{t}$-test, $\mathrm{p}<.02)$. However, the food 


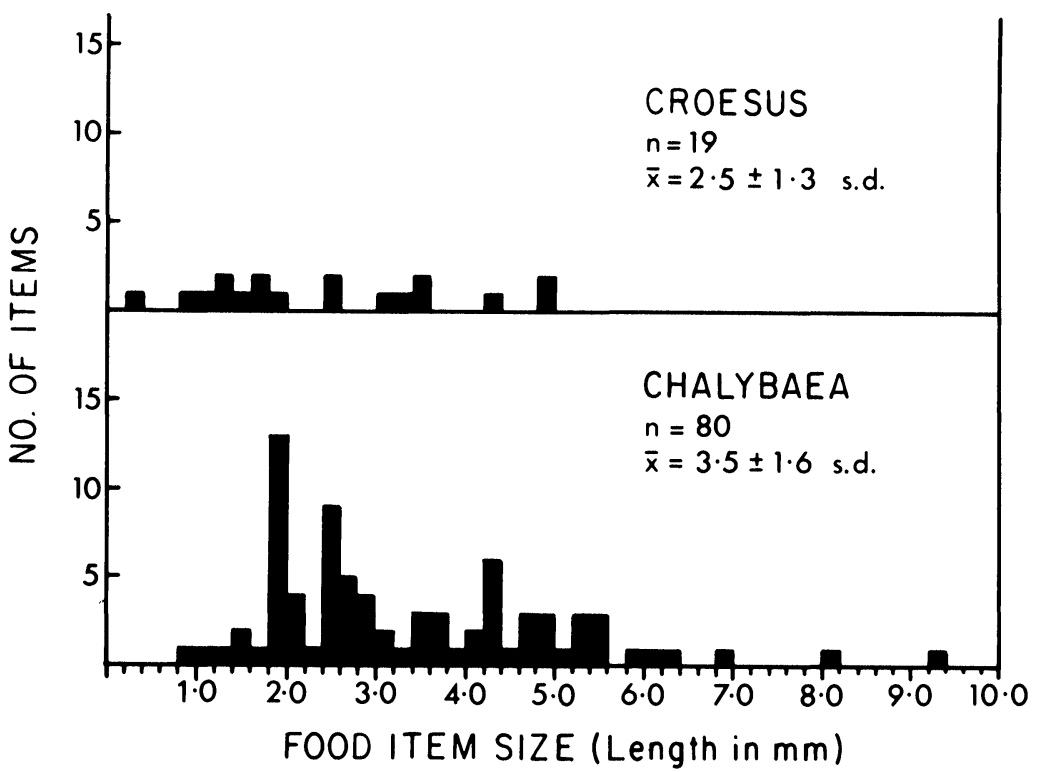

Figure 3. Frequency distributions of the lengths of food items taken from 80 chalybaea foragers and 19 croesus foragers (see Tables 5 and 6). Each distribution is based on workers from one colony only.

size distributions are based on limited single-nest samples, and there is likely to be significant temporal and spatial heterogeneity within, as well as between, species.

Additional studies on food item diversity and overlap in $R h y$ tidoponera are desirable. Such studies are feasible for ants which are primarily lone-foraging predators and scavengers, because of the discrete, visible nature of most foraged items. However, difficulties remain in assessing the importance of honeydew and other liquid foods, which may be carried in the crop as well as between the mandibles.

Two species in the impressa group were recorded collecting honeydew from homopterans. Workers of chalybaea were seen tending coccids on a fresh shoot emerging from the trunk of a camphor laurel tree (Cinnamomum camphora), in the Sydney region. $R$. purpurea workers were observed tending aphids on ginger plants (Alpinia caerulaea) in several places at Lake Eacham, Qld. 
In one of the latter instances, observations were made intermittently over a period of 2 days, during which time a force of about 15 workers was regularly maintained on the plant. These workers gave outward-facing aggressive displays (mandibles barred) when the plant was disturbed. A small contingency of workers was also clustered among leaf litter at the base of the plant, apparently controlling access to the plant and aphids. Detense of "tending rights" may be important since other aggressive, aphid-tending ants such as Pheidole were present in the same locality. The colony of the purpurea workers was located in a rotten log $5 \mathrm{~m}$ distant. Workers returning to the colony from the ginger plant showed high fidelity to a particular route which involved following the ground for half the distance and then proceeding along a decumbent liana (one of many) which led back to the log.

Thus, despite the "lone forager" status of most impressa group workers, short-term recruitment, co-operative food retrieval, and (in at least one species) persistent, long-range trails, may be used. Excepting persistent trails, species in the impressa group appear to show a level of individual foraging and recruitment similar to that described for the myrmicine ant, Novomessor (Hölldobler, et al., 1978).

The species in the impressa group with the most sophisticated foraging and recruitment behavior (purpurea) is the only member whose colonies are entirely monogynous and queenright. It is tempting to speculate that widespread polygyny and worker reproduction in other Rhytidoponera species may have constrained ergonomic improvements because of a reduction in the efficacy of colony-level selection (cf. Oster \& Wilson, 1978).

\section{SUMMARY}

The five known species of the Rhytidoponera impressa group collectively inhabit a variety of mesic forest habitats (from wet sclerophyll to tropical rainforest) along the east coast of Australia, with one species (purpurea) also occurring in montane rainforest of New Guinea. $R$. chalybaea has invaded mesic anthropogenic habitats (parks and gardens) in the Sydney region. All species show partial sympatry with at least one other species.

Most colonies are located in rotten logs or under stones. There are significant differences between species in the frequencies with 
which different nest sites are utilized, and these preferences are correlated with the availability of potential nest sites. The more tropical species (impressa and purpurea) show a stronger preference for rotten logs, but occur at lower nest densities, than inhabitants of temperate and subtropical rainforest (confusa and chalybaea). Where confusa and chalybaea occur sympatrically, they have significantly lower nest densities than allopatrically.

Workers of the impressa group are generally lone-foraging predators and scavengers, but co-operative food retrieval and recruitment to food sources occur to a limited degree. The majority of food items are small arthropods: other ant species may be a significant component of the diet. Foraging usually occurs among leaf litter and logs on the ground but at least two species (chalybaea and purpurea) also forage on low foliage and tend homopterans.

\section{REFERENCES}

Brown, W. L.

1953. Characters and synonymies among the genera of ants. Part I. Breviora, 11, 1-13.

1954. Systematic and other notes on some of the smaller species of the ant genus Rhytidoponera Mayr. Breviora, 33, 1-11.

1958. Contributions toward a reclassification of the Formicidae. II. Tribe Ectatommini (Hymenoptera). Bull. Mus. Comp. Zool. Harvard, 118, 175-362.

Haskins, C. P. AND W. M. Whelden.

1965. "Queenlessness", worker sibship, and colony versus population structure in the formicid genus Rhytidoponera. Psyche, 72, 87-112.

Hölldobler, B., R. C. Stanton and H. Markl.

1978. Recruitment and food-retrieving behavior in Novomessor (Formicidae, Hymenoptera). I. Chemical signals. Behav. Ecol. Sociobiol., 4, 163-181.

Oster, G. F. AND E. O. Wilson

1978. Caste and ecology in the social insects. Princeton University Press, Princeton, N.J.

Specht, R. L., E. M. Roe and V. H. Boughton

1974. Conservation of major plant communities in Australia and Papua New Guinea. Aust. J. Bot. Suppl. No. 7.

WARD, P. S.

1978. Genetic variation, colony structure, and social behaviour in the Rhytidoponera impressa group, a species complex of ponerine ants. Ph.D. thesis, University of Sydney.

1980. A systematic revision of the Rhytidoponera impressa group (Hymenoptera: Formicidae) in Australia and New Guinea. Aust. J. Zool. 28 , 475-498. 
1981. Ecology and life history of the Rhytidoponera impressa group (Hymenoptera: Formicidae). II. Colony origin, seasonal cycles, and reproduction. Psyche, 88: 109-126.

WeBB, L. S.

1978. A structural comparison of New Zealand and south-east Australian rain forests and their tropical affinities. Aust. J. Ecol. , 7-21.

WHELDEN, W. M.

1957. Anatomy of Rhytidoponera convexa. Ann. Ent. Soc. Am., 50, 271-282.

1960. Anatomy of Rhytidoponera metallica. Ann. Ent. Soc. Am., 53, 793-808. WILSON, E. O.

1958. Studies on the ant fauna of Melanesia. III. Rhytidoponera in western Melanesia and the Moluccas. IV. The tribe Ponerini. Bull. Mus. Comp. Zool. Harvard, 119, 303-371.

1959. Some ecological characteristics of ants in New Guinea rain forests. Ecology, 40, 437-447. 

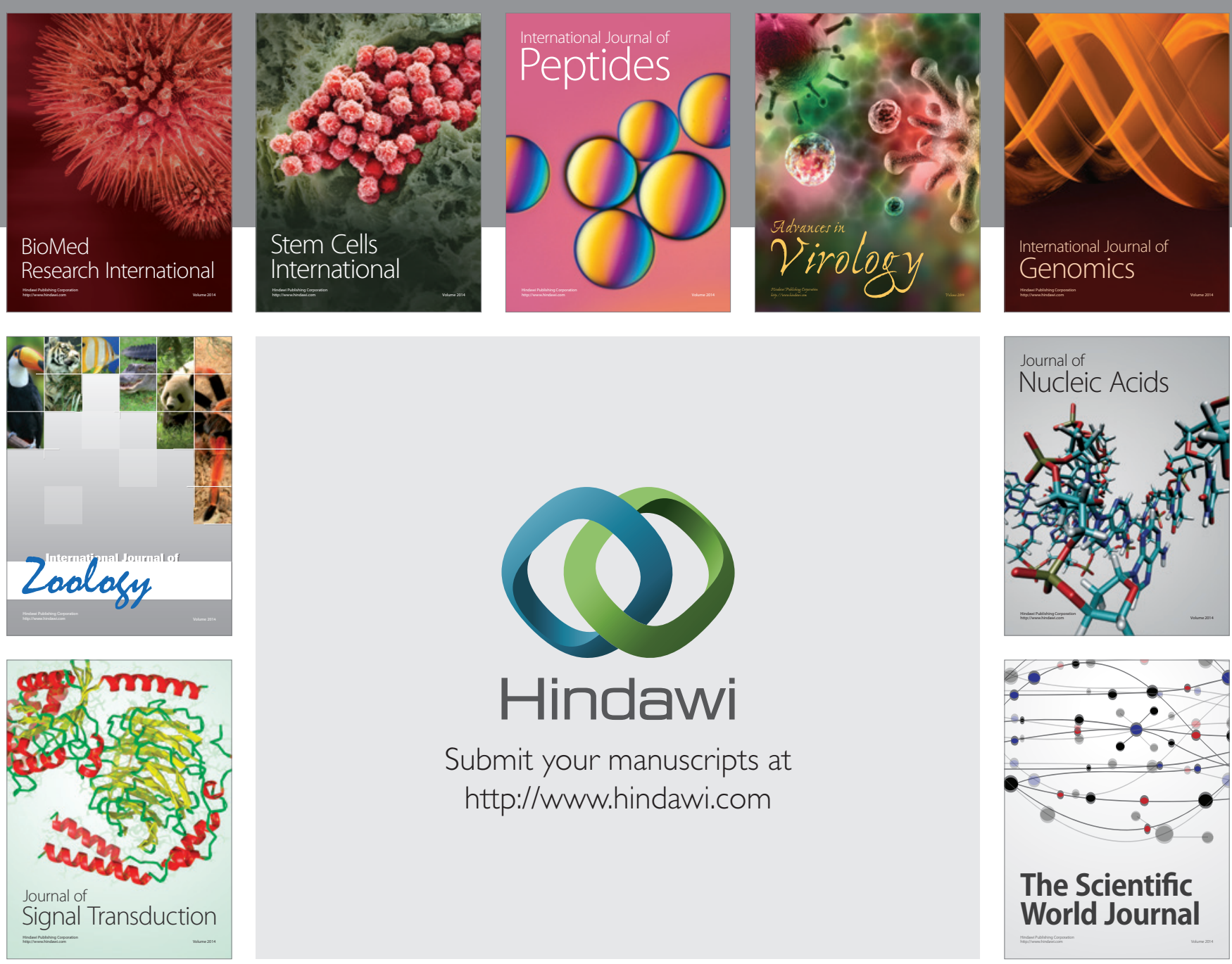

Submit your manuscripts at

http://www.hindawi.com
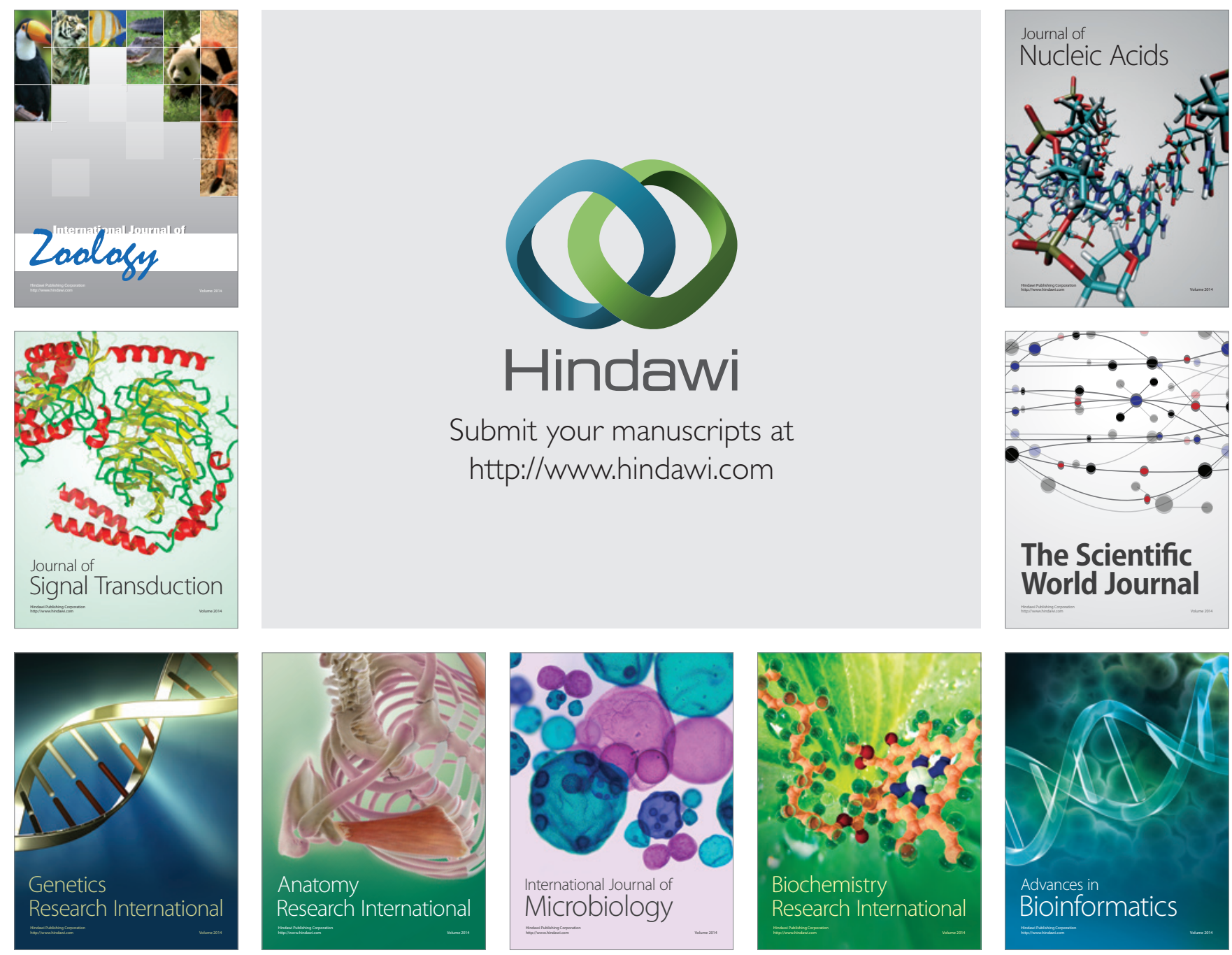

The Scientific World Journal
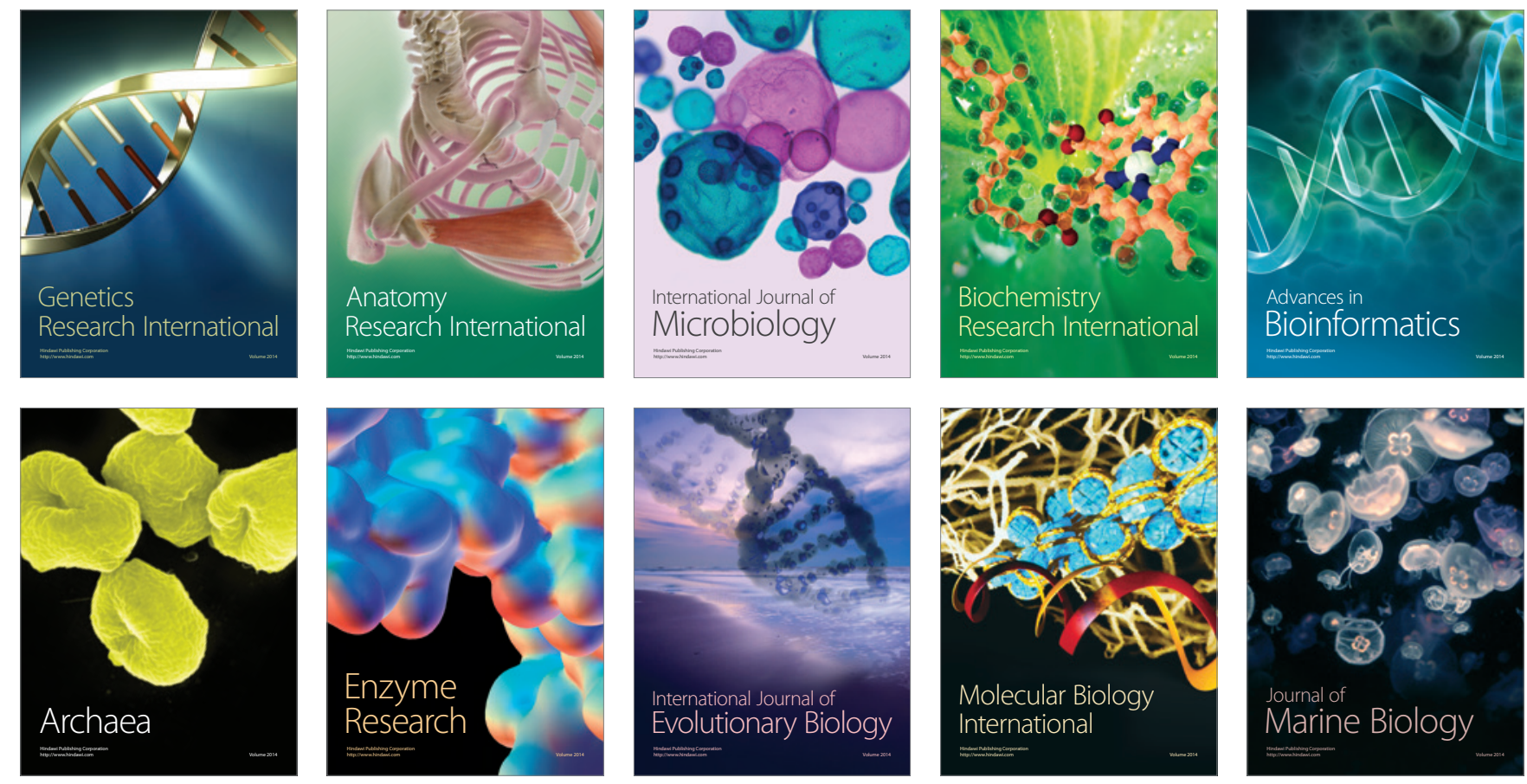